\title{
Metacognitive Attitude and Ability of Students and Teachers on Science Program Class
}

\author{
Yanti Herlanti ${ }^{1}$, R. Bambang Aryan Soekisno, ${ }^{2}$ \\ ${ }^{1}$ Universitas Islam Negeri Syarif Hidayatullah, Jakarta, Indonesia \\ ${ }^{2}$ Tenth Senior High School of Bogor, Indonesia
}

\begin{abstract}
Metacognitive knowledge becames a target on Indonesia curriculum to improve the accomplishment of Indonesian students' higher order thinking skill. The study aimed to explore the metacognitive attitude and ability of teachers and students in Science Program Class. The study used survey research design. There were 166 students and 30 teachers involved in this study. The study found that more than $70 \%$ of students have did 36 attitudes of metacognitive, but $40 \%-50 \%$ of students rarely did four attitudes of metacognitive in their learning. All of teachers have done all aspect of metacognitive attitude in their teaching. However, teachers and students have low science metacognitive ability. The mean of metacognitive score test is around 0 to 33. No Significant relations between metacognitive attitude and metacognitive ability. Based on the findings, the study suggests that school should develop drawing pictures or diagrams to help students understand while learning, using the organizational structure of the text to help students learn, asking their self question about the material before they begin the learning, and asking their self question about the material before they begin.
\end{abstract}

Keywords: Metacognitive, ability, attitude, science content DOI: https://doi.org/10.1166/asl.2018.11726

\section{INTRODUCTION}

Metacognitive knowledge (also known as metacognitive awareness) lays the foundation for the development of self-regulation, which is an essential prerequisite for independent and self-directed learning. Metacognitive knowledge is an awareness of and knowledge about one's own cognition or the emphasis on helping students become more knowledgeable of and responsible for their own cognition and thinking? Metacognitive awareness lead to the development of stronger cognitive skills and deeper information processing. Metacognitive awareness consists of two kinds of knowledge, i.e. knowledge of cognition and regulation of cognition ${ }^{11}$. Knowledge of cognition is in the form of declarative, procedural, and conditional. Meanwhile, the regulation of cognition covers planning, information strategies, comprehension monitoring, debugging strategies, and evaluation.

Metacognition refers to higher order thinking, which involves active control over the cognitive processes engaged in learning ${ }^{5}$. One of the indicators of higher order thinking is scientific literacy. In Program for International Assesment (PISA) 2012, the mathematical

*Email Address: yantiherlanti@uinjkt.ac.id and scientific literacy of Indonesian students ranked 64 out of 65 participant's countries and its score was below World average score. So metacognitive knowledge becomes a target in improving the accomplishment of Indonesian students' higher order thinking skill. According to the decree of Minister of Education and Culture Number 20 in 2016, Indonesia curriculum has set the standard on metacognitive knowledge.

Metacognitive knowledge could be explore by Metacognitive Awareness Inventory (MAI) and Test of metacognitive knowledge. Schraw \& Dennison developed Metacognitive Awareness Inventory (MAI) to explore knowledge aspect of cognition and regulation of cognition from learners ${ }^{11}$. MAI designed to discover metacognitive awareness during learning process. The instrument presented fifty-three reflective questions. Rampayom developed further about Metacognitive Inventory on the knowledge aspect that consists of declarative, procedural, and conditional knowledge ${ }^{10}$. Unlike Schraw \& Dennison who had developed knowledge of cognition based on the reflection of learning in general, Rampayom developed metacognitive inventory according to specific subject content that is Chemistry.

Furthermore, Balcikanli re-developed Schraw \& Dennison's metacognitive awareness inventory as 
Metacognitive Awareness Inventory Teacher (MAIT) ${ }^{2}$. The inventory was particularly designed for teacher, aimed at exploring teacher's metacognitive awareness during teaching process. The aspects explored in metacognitive inventory are declarative, procedural, and conditional knowledge, planning, monitoring, and evaluating. There were twenty-four reflective questions in MAIT instrument.

The study aimed to explore metacognitive attitude in teaching and learning process, as well as metacognitive knowledge especially in science content. The study, then, focuses on the following research questions: How are the students' metacognitive attitude and ability? Are there any relations between students' metacognitive attitude and ability? How are the teachers' metacognitive attitude and ability?

\section{METHODOLOGY}

\section{Methods}

The study uses survey research design. A survey is conducted in Public Senior High Schools in Bogor. The city is selected due to several reasons. Firstly, it is a small city that lies between urban and rural area. Secondly, the average of schools' integrity index in National Examination for Science Program Class was 89.72. Schools' integrity index showed how students and schools did national examination honestly and obtained fairly. The Indonesia ministry of education determined the level of integrity index. Integrity index less than 80 indicates low integrity, integrity index more than 80 indicates high integrity. The number shows that the science program students in Bogor have a high integrity. The high integrity becomes a foundation in the questioners filled honestly by the students, which also shows the real condition.

\section{Population and Sample}

There are ten public senior high schools in Bogor. Schools in West Bogor district are selected as the samples. The schools' integrity index for Science Class Program in National Examination was 87.40.

The public senior high schools in West Bogor have 878 students and 52 teachers. Science Program Class have 585 students and 34 teachers. Sample is randomly selected in Science Program Class, i.e. two classes in grade $10^{\text {th }}, 11^{\text {th }}$, and $12^{\text {th }}$. The number of the sample is 166 students of science program class with the age from 14 until 18 years old and average in 15.2 years old, 76 students are male, and 90 students are female. The number of samples is 30 teachers, with the age from 24 until 59 years old and average in 56.25 years old, 14 teachers are male and 16 teacher are female.
Metacognitive Awareness Inventory Teacher (MAIT), and Metacognitive Knowledge Test. MAI is used to explore students' metacognitive attitude in learning process. Meanwhile, MAIT is used to explore teachers' metacognitive attitude in teaching process. Metacognitive Knowledge Test is to explore metacognitive ability, which relates to specific content, i.e. science mathematical content.

MAI is adapted from Schraw \& Dennison ${ }^{11}$. MAI is adapted to Indonesian context. It is translated into Indonesian language. MAI is modified from measuring awareness (with disagree-agree rating scale) into measuring attitude (with execution frequency standard rating scale). Psychology experts then validate MAI's content. Then the content's instrument reading and context validation is tested to 40 students, age $15-16$ years old. The validation result of the content and context shows that there are 40 valid questions, which have alpha Cronbach score around 0,879.

MAIT is adapted from Balcikanli ${ }^{2}$. MAIT is also translated into Indonesian language. MAIT is modified from measuring awareness from measuring awareness (with disagree-agree rating scale) into measuring attitude (with execution frequency standard rating scale). Psychology experts validate MAIT's content, and then its context validation is tested to 40 teacher candidates who already have teaching experience for at least six moths. The result shows that there are 20 valid questions with alpha Cronbach score around 0,860 .

Meanwhile, metacognitive knowledge test is adapted from Rampayom ${ }^{10}$. There are three aspects explored in metacognitive knowledge, they are declarative, procedural and conditional knowledge. Declarative knowledge is explored by an question, such as: "What is the relevant information required to be able to answer question number 1 correctly? Explain your answer!" Procedural knowledge is explored by the following question: "Explain your thoughts step by step so that your answer conclusion is related to your explanation for question number 1!" Conditional knowledge is explored by a question as: "In which condition do you think you assume that the steps in question number 3 is relevant to answer question number 1?" Metacognitive knowledge test is administered to 82 students of Science program and 10 teachers of Mathematics and Science. The instrument of metacognitive knowledge is Science PISA test that added metacognitive knowledge.

\section{Data Analysis}

The data is analyzed descriptively to find its data dispersion and mean. Rho Spearman Correlation Test is used to analyze the relations between metacognitive attitude and knowledge of students as well as teachers.

\section{Instrument}

There are three instruments used in the study, i.e. Metacognitive Awareness Inventory (MAI), 


\section{RESULTS AND DISCUSSION}

\section{Students' Metacognitive Attitude}

Metacognitive attitude explores students' assumption based on their learning experience. There is no gender bias in metacognitive attitude. It can be seen in mean test (t-test). The result of male and female students' metacognitive attitude shows hardly any difference $(\mathrm{F}=2.42$, Sig. 0.12). Metacognitive attitude has no relations to students' age. The result of Rho Spearman test shows that there is no significant relation between age and metacognitive attitude ( $\mathrm{r}=-0.51$, Sig. 0.66).

Metacognitive attitude measures two aspects related to knowledge and regulation of cognition. Knowledge of cognition consists of declarative, procedural, and conditional knowledge. Regulation of cognition contains planning, information management strategies, comprehension monitoring debugging strategies, and evaluation. The result of knowledge and regulation of cognition aspects can be viewed in Figure 1. The further details of each question results on metacognitive attitude can be seen in figure 2 .

\begin{tabular}{|c|c|}
\hline Evaluation & \begin{tabular}{l|l|l|l|} 
& & $\mid$ & \\
& & &
\end{tabular} \\
\hline Debuging strategies & 3,3 \\
\hline Comprehensin monitoring & 1 \\
\hline information managemen & 3,0 \\
\hline Planning & 1 \\
\hline Conditional Kowledge & \begin{tabular}{|l|l|l|} 
& 3,4
\end{tabular} \\
\hline Prosedural knowledge & 3,3 \\
\hline Deklarative knowledge & \begin{tabular}{|l|l|l|l|} 
& & & \\
& & 3,2 \\
\end{tabular} \\
\hline & $\begin{array}{lllll}0 & 1,5 & 2,0 & 2,5 & 3,0\end{array}$ \\
\hline (1.0: Never) (2.0: se & $\begin{array}{l}\text { Rating Scale } \\
\text { dom) (3.0: Sometimes) (4.0 often) }\end{array}$ \\
\hline
\end{tabular}

Figure 1. The accomplishment of Students' Metacognitive Attitude

Figure 1 shows that the students' attitude has been accustomed to conditional knowledge and debugging strategies. There are two aspects that the students have not been familiar with, i.e. information strategies and evaluation. Table 1 shows the aspects that the students hardly, rarely, seldom, and always do.

The question number $8,23,24,30,31,33,37$ showed the aspect of Information strategies. Figure 2 showed there were three questions (number 24, 30, 33) with lower acquisition. Table 1 shows almost $32 \%$ of students rarely did to create their own examples to make information meaningful. Almost $51 \%$ of students rarely did to draw pictures or diagrams to help them understand while learning. Almost $50 \%$ of students rarely did to use the organizational structure of the text to help them learn.

The question number $3,14,18,29$, and 39 showed the aspect of evaluation. Figure 2 showed there were one questions (number 18) with lower acquisition. Table 1 shows almost $36 \%$ of students rarely do to summarize what they have learned after they finished.

Table 1. Metacognitive Attitude that Students Rarely Do

\begin{tabular}{|c|c|c|c|c|c|}
\hline \multirow{2}{*}{$\begin{array}{l}\text { Aspect of } \\
\text { Metacognitiv } \\
\text { e Awareness }\end{array}$} & \multirow[b]{2}{*}{ Question } & \multicolumn{4}{|c|}{ Sum of Students (\%) } \\
\hline & & 1 & 2 & 3 & 4 \\
\hline \multirow[t]{3}{*}{$\begin{array}{l}\text { Declarative } \\
\text { knowledge }\end{array}$} & $\begin{array}{l}\text { 7. I am good at } \\
\text { organizing } \\
\text { information }\end{array}$ & 1.8 & 24.24 & 58.18 & 15.78 \\
\hline & $\begin{array}{l}\text { 12. I am good at } \\
\text { remembering } \\
\text { information }\end{array}$ & 0.6 & 21.69 & 59.63 & 18.07 \\
\hline & $\begin{array}{l}25 . \text { I am a good } \\
\text { judge of how well I } \\
\text { understand } \\
\text { something }\end{array}$ & 1.2 & 25.3 & 49.4 & 24.1 \\
\hline $\begin{array}{l}\text { Procedural } \\
\text { knowledge }\end{array}$ & $\begin{array}{l}26 . \text { I find myself } \\
\text { using } \\
\text { learning strategies } \\
\text { automatically }\end{array}$ & 1.8 & 27.71 & 46.39 & 24.1 \\
\hline Planning & $\begin{array}{l}16 . \text { I ask myself } \\
\text { questions about the } \\
\text { material before I } \\
\text { begin }\end{array}$ & 6.63 & 32.53 & 42.77 & 18.07 \\
\hline \multirow[t]{3}{*}{$\begin{array}{l}\text { Information } \\
\text { management } \\
\text { strategies }\end{array}$} & $\begin{array}{l}\text { 24. I create my own } \\
\text { examples to make } \\
\text { information more } \\
\text { meaningful }\end{array}$ & 3.01 & 28.31 & 37.95 & 30.72 \\
\hline & $\begin{array}{l}\text { 30. I draw Picture } \\
\text { or diagrams to help } \\
\text { me understand } \\
\text { while learning }\end{array}$ & 9.64 & 40.96 & 30.72 & 18.67 \\
\hline & $\begin{array}{l}33 . \text { I use the } \\
\text { organizational } \\
\text { structure of the text } \\
\text { to help me learn }\end{array}$ & 8.47 & 40.96 & 34.34 & 16.27 \\
\hline $\begin{array}{l}\text { Comprehensi } \\
\text { on monitoring }\end{array}$ & $\begin{array}{l}\text { 27. I find myself } \\
\text { pausing regularly to } \\
\text { check my } \\
\text { comprehension }\end{array}$ & 3.61 & 27.71 & 46.99 & 21.69 \\
\hline Evaluation & $\begin{array}{l}\text { 18. I summarized } \\
\text { what I have learn } \\
\text { after I finish }\end{array}$ & 5.42 & 30.12 & 45.78 & 18.67 \\
\hline
\end{tabular}

Note: $1=$ Never, $2=$ Seldom, $3=$ Sometimes, $4=$ Often

The figure 2 also shows that according to students' perception, the attitudes that they hardly do is in question number $7,12,16,25,26$, and 27 . Table 1 shows almost $40 \%$ of students rarely did to ask their selfquestion about the material before they begin the learning. Almost $25 \%$ of students rarely did the good at organizing information. Almost $22 \%$ of students rarely did the good at remembering information. Almost $26 \%$ of student rarely did the good judge of how well they understand something. Almost $30 \%$ of students rarely did to find their self-using helpful learning strategies automatically. Almost $40 \%$ of students rarely did to ask their self-question about the material before they begin. Almost $31 \%$ of students rarely did to find their self pausing regularly to check their comprehension. 


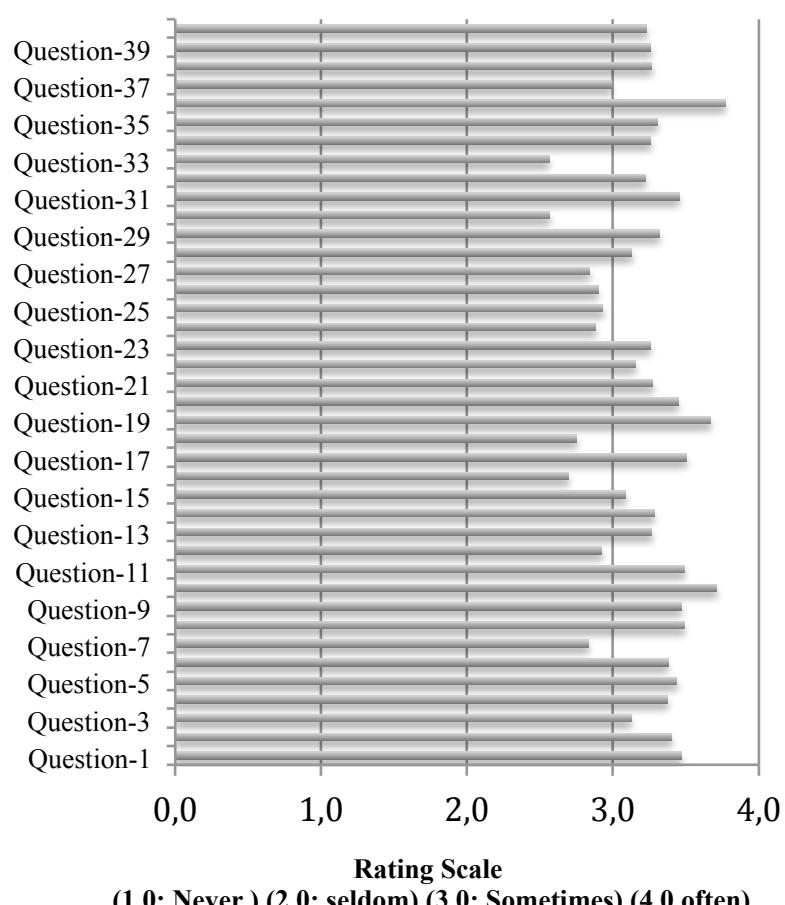

Figure 2. Students' Metacognitive Attitude

\section{Students' Science Metacognitive Ability}

Metacognitive ability is explored by the test result of the Mathematical and Science content question. The question is related to global warming topics. There is no gender bias in the questions. The results of t-test on the test score of metacognitive ability shows no significant difference ( $F=0.026$, Sig. 0.87). However, based on Rho Spearman test there is significant correlation between test score and metacognitive ability ( $r=-0,245$ Sig. 0.03 ). The older the age of the students, the lower the score of metacognitive ability.

Metacognitive ability test result shows low yield, either in declarative, procedural, and conditional knowledge. The result of metacognitive test is avarege below 35. Meanwhile, the result of conditional knowledge is average below 5. The test result of Mathematical and Scientific knowledge can be viewed in figure 3 .

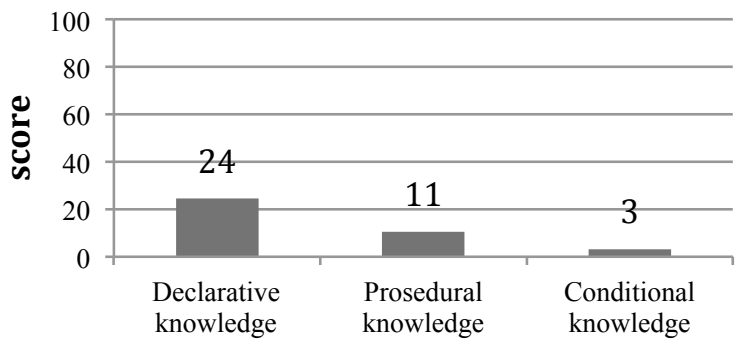

Figure 3. Students' Metacognitive Ability

The declarative knowledge aspect of metacognitive ability is marked by the ability to find relevant information in order to answer the available questions. Students mostly exposed one of two relevant information. The example of question and answer of declarative knowledge can be seen in S-1 answer. In the S-1 answer, student mentions particularly one relevant information, i.e. graph. Student mentions knowledge by stating 'the knowledge'; however, the meaning of the knowledge has not been clear yet.

What is relevant information required to be able to answer question number 1 correctly?

Answer: graph and the knowledge. If we have the knowledge, the accurate graph will be supported by the knowledge.

\section{- S-1 Answer-}

Procedural knowledge aspect of metacognitive competence is characterized by the ability to express systematical steps in order to find the appropriate answer. The example of question and answer of procedural knowledge can be seen in S-2 answer. In his answer, S-2 succeeded in discovering the necessity in observing the graph. However, he failed in finding that it is necessary to compare and connect the two graphs in order to obtain a valid conclusion.

Explain your thoughts step by step so that your conclusion is related to your answer for question number 1 ?

Answer: I have already learnt that carbon dioxide makes the atmosphere thinner. Then, I have got a graph. Therefore, I agree to Zaim argument/conclusion.

\section{- S-2 Answer-}

Conditional knowledge aspect of metacognitive competence is indicated by the ability to think flexibly, i.e. in which condition we use certain answer, and why the answer becomes the correct one. The example of question and answer of conditional knowledge can be seen in S-3 answer. In his answer, it is obvious that there is no relation between the question and answer.

In which condition do you think that steps in question number 3 are appropriate to answer question number 1 ?

Answer: The temperature in the surroundings is hot because there is a lot of forest fire.

\section{- S-3 Answer-}

\section{Relations between students' metacognitive attitude and ability}

Metacognitive ability in science mathematical field for declarative, procedural and conditional knowledge is quite poor. Nevertheless, according to the students' perception, metacognitive attitude for declarative, procedural and conditional knowledge is quite high. Based on the result, there is a contradiction. However, according to the result of Rho Spearman correlation test, the contradictive relation particularly between procedural and conditional knowledge shows insignificant difference. The result of correlation test between metacognitive attitude and the accomplishment of metacognitive knowledge in mathematical and scientific learning can be seen in Table 2 .

\section{Teachers Metacognitive Attitude}

Metacognitive attitude explores teachers' perception based on the teaching experience. There is no gender bias that can be seen in t-test result. The result of 
female and male teachers' metacognitive attitude shows no significant difference $(\mathrm{F}=0.46$, Sig. 0.50). Metacognitive attitude has no relation to the teachers' age. The result of Rho Spearman shows no significant correlation between age and metacognitive attitude $(r=$ 0.33, Sig. 0.08).

Table 2. Correlation between metacognitive attitude and ability

\begin{tabular}{|r|l|l|l|l|}
\hline \multicolumn{2}{|c|}{} & \multicolumn{3}{|c|}{$\begin{array}{c}\text { Metacognitive ability in Mathematical and } \\
\text { scientific learning }\end{array}$} \\
\cline { 3 - 5 } \multicolumn{2}{|c|}{} & Declarative & Procedural & Conditional \\
\hline \multirow{4}{*}{$\begin{array}{c}\text { Metacognitive } \\
\text { attitude }\end{array}$} & Declarative & $\begin{array}{l}\mathrm{r}=0.04 \\
\text { Sig. 0.72 }\end{array}$ & & \\
\cline { 2 - 5 } & Procedural & & $\begin{array}{l}\mathrm{r}=-0.03 \\
\text { Sig. } 0.78\end{array}$ & \\
\cline { 2 - 5 } & Conditional & & & $\begin{array}{l}\mathrm{r}=-0.14 \\
\text { Sig. } 0.21\end{array}$ \\
\hline
\end{tabular}

Metacognitive attitude measures two aspects related to the knowledge and regulation of cognition. The knowledge of cognition consists of declarative, procedural and conditional knowledge. The regulation of cognition consists of planning, monitoring, and evaluation. The result of the knowledge and regulation of cognition in teachers' according to teachers' perception can be seen in Figure 4.

In figure 4, it is obvious that teachers have positive metacognitive attitude I teaching process. Metacognitive attitude reaches between 3 and 4, it's means teahcers did metacognitive attitude in their teaching.

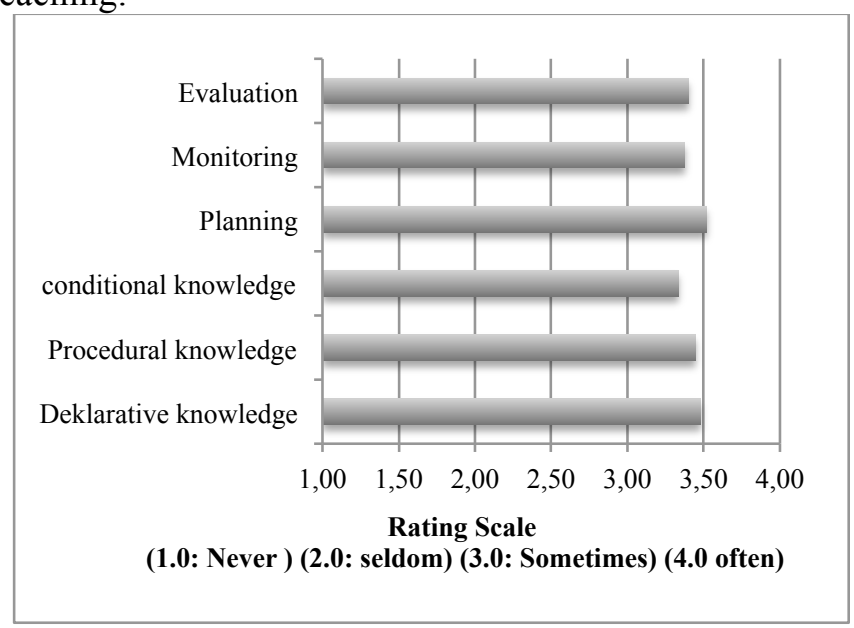

Figure 4. Teachers' Metacognitive Awareness

Figure 5 shows the details illustration to every question. The figure also shows that the metacognitive attitude in all aspects is positive. It means that most teachers have been accustomed to metacognitive attitude.

\section{Teachers' Science Mathematical Metacognitive Ability}

Metacognitive ability test is administered to teachers of science (Physics, Chemistry, and Biology) and Math. The result of metacognitive ability can be seen in figure 6. The figure shows the gain of test result in declarative, procedural, and metacognitive knowledge is extremely poor, which is around $0-33$.

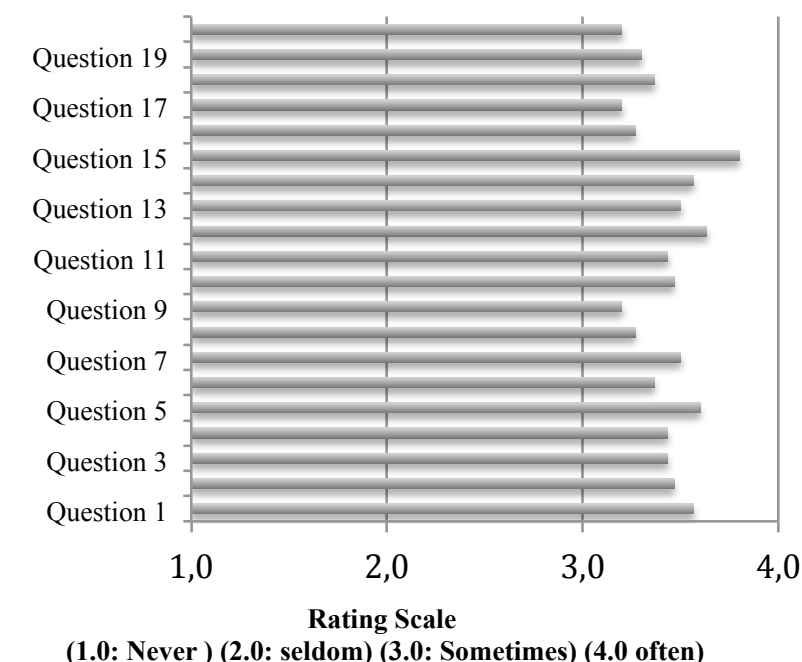

Figure 5. Teacher's Metacognitive Awareness in Each Question

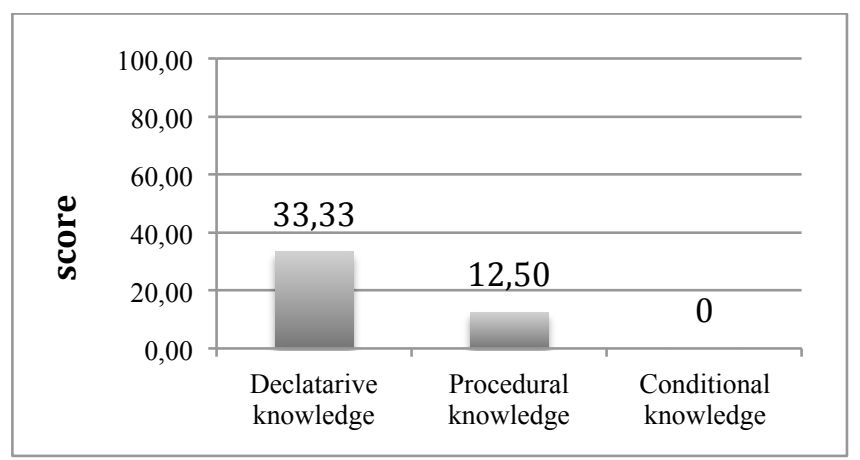

Figure 6. Teachers' Science Mathematical Metacognitive

\section{Discussion} Ability

The metacognitive attitudes of teachers and students have already good. The gain in teachers as well as students have done metacognitive attitude, although $40 \%-50 \%$ of students still rarely did in four attitudes of metacognitive, but more than $70 \%$ of students have done thirty six (36) attitudes of metacognitive. On the other hand, the mean of the gain in science metacognitive ability is below 30. There was a contradiction between metacognitive attitude and ability. Teachers as well as students were failed to understand free concept question, in which test takers were asked to observe and compare two graphs. Both teachers and students still focused on concept and theory hence they failed to develop metacognitive knowledge. The previous study has shown the similar pattern. Students have the potential to develop their metacognitive ${ }^{4}$. The students obtained high average score in metacognitive attitude (potential zone). However, factually the ability of metacognitive knowledge in Biology topics is low (actual zone). Based on the findings, it is important to attract students in actual zone (the low level of students' metacognitive ability into the ideal zone (high metacognitive attitude and ability).

Teachers need to be trained a teaching and learning which can improve the students' metacognitive 
ability. Based on the students' answer, it is obvious that students have not been able to comprehend the problem hence they failed to solve it. There are four steps in problem solving, i.e. understanding the problem, planning the solution, executing the solution, and reviewing the result (solution) ${ }^{8}$. Based on Polya's-four steps, students and teachers have failed in the first step, thus they could not proceed to the next steps and finally they failed to answer the question correctly.

It is advisable that the teaching and learning process should apply problem-based learning. Several studies have pointed out that problem solving is effective in improving metacognitive ability. Student who often used problem-solving methods performs better competence in analyzing steps and combining the easiest method to the most difficult one ${ }^{1}$. Problem based learning is more effective in improving the metacognitive awareness level and positive attitude in Science learning (Chemistry) ${ }^{12}$.

In understanding the problem, students need literacy competence. The absence of the competence will lead students to fail in understanding the problem. It's obvious that four attitudes of metacognitive was rarely done by students related with literacy. As the found that almost $51 \%$ of students rarely did to draw pictures or diagrams to help them understand while learning, almost $50 \%$ of students rarely did to use the organizational structure of the text to help them learn, almost $40 \%$ of students rarely did to ask their self question about the material before they begin the learning, and almost $40 \%$ of students rarely did to ask their self question about the material before they begin.

There are several techniques to improve literacy competence while improving metacognitive attitudes that are rarely do. Genlott \& Gronlund suggested iWTR technique ${ }^{3}$. IWTR stands for integrated write to learn. There are five steps in iWTR technique. First, the teacher planned the lessons by choosing which abilities, core content, and knowledge requirements. Second, the teacher was to inspire the students in conjunction with setting the topic. Third, before the students began writing it was important to give them knowledge concerning how that particular text genre was to be written. Forth, after making this introduction the students began writing while getting linguistic support from the teacher and feedback from both their peers and the teacher. Fitth, depending on topic and type of assignment the texts were either written and published directly on the class web site or written in a document shared with teachers and peers. Finally, some kind of formative assessment by the teacher and the students were made.

The other strategy that can be implemented to improve literacy and metacognitive attitudes is SQ3R, which stands for survey, question, read, recite, and review. A study shows that the implementation of SQ3R able to improve students' competence in reading comprehensive9. Furthermore, PQ4R strategy; which stands for preview, question, read, reflect, recite, and review; can also be applied in improving students' literacy competence. PQ4R could improve comprehension and retention. This can lead to better grades and achievement in all subject areas ${ }^{6}$.

\section{CONCLUSIONS}

Students and teachers' metacognitive attitude in science class has already been well performed, although $40-50 \%$ of students still rarely did in four attitudes of metacognitive. However, the metacognitive ability is still quite poor and needs an extra attention. Many students rarely did in drawing pictures or diagrams to help them understand while learning, using the organizational structure of the text to help them learn, asking their self question about the material before they begin the learning, and asking their self question about the material before they begin.

\section{REFERENCES}

[1] Antonietti, A., Ignazi, S., Perego, P. (2000). Metacognitive Knowledge about Problem Solving Methods. British Journal of Educational Psychology, 70, 1-16.

[2] Balcikanli, C. (2011). Metacognitive Awareness Inventory for Teacher (MAIT). Electronic Journal of Research in Educational Psychology, 9(3), 1309-1332.

[3] Genlott, A.A., \& Gronlund, A. (2013). Improving literacy skills through learning reading by writing: The iWTR method presented and tested. 67, 98-104.

[4] Herlanti, Y. (2015). Kesadaran Metakognitif dan Pengetahuan Metakognitif Peserta Didik Sekolah Menengah Atas dalam Mempersiapkan Ketercapaian Standar Kelulusan Pada Kurikulum 2013. Cakrawala Pendidikan, 34(3), 357-367.

[5] Livingston, J.A. (1997). Metacognition: An Overview. Retrieved from http://gse.buffalo.edu/fas/shuell/CEP564/Metacog.htm

[6] Logsdon, A. (2016). How the PQ4R Strategy Improves Reading Comprehension: This strategy increases reading understanding and recall. Retrived from https://www.verywell.com/strategyimproves-reading-comprehension-2162266

[7] Pintrich, P.R. (2002). The Role of Metacognitive Knowledge in Learning, Teaching, and Assessing. Theory into Practice 41(4), 221-225.

[8] Polya, G. (1973). How to Solve It: A New Aspect of Mathematical Method. New Jersey: Princeton University Press.

[9] Rayanto, Y.H. \& Rusmawan, P.N. (2016). Implementation of SQ3R Strategy on Learning Reading Comprehension. IOSR Journal of Research \& Methods in Education, 6(1), 21-30.

[10] Rompayom, P., Tambunchong, C. Wongyou- noi, S., \& Dechsri, P. (2010). "The Development of Metacognitive Inventory to Measure Students' Metacognitive Know- ledge Related to Chemical Bonding Conceptions". Paper Presented at International Association for Educational Assessment (IAEA). Retrievedfrom http://www.iaea.info/documents/paper 4d52b63.pdf

[11] Schraw, G. \& Dennison, R.S. (1994). Assessing Metacognitive Awareness. Contemporary Educational Psychology, 19, 460-475.

[12] Tosun, C. \& Senocak, E. (2013). Problem Based Learning on Metacognitive Awareness and Attitude Toward Chemistry of Prospective Teacher with Different Academic Backgrounds. Australian Journal of Teacher, 38 (3), 61-73 